\title{
Teaching a five-paragraph essay
}

\section{Ganesh Kumar Bastola}

Writing an essay requires usto think through whatwe are going to do. Every essay has a beginning, middle, and an end (Levin, 1997). In a five-paragraph essay, the first paragraph is generally understood as introduction. An effective introduction demands readers' interest and give them a sense of the topic and purpose (Gardner, 2005). The next three paragraphs consist of the body of the essay. The body of the essay explains and supports the thesis with details; further develops ideas in a clear sequence. The fifth paragraph is conclusion. It incorporates the importance of the thesis statement, reflects on the larger significance of the topic, and brings the essay to a logical manner (Gardner, 2005).

In an essay, a thesis statement is a complete sentence that contains one main idea. This idea controls the content of the entire essay. Moreover, the thesis statement should express a complete thought. It is often placed at the end of the introductory paragraph which is usually one sentence. The subsequent paragraph begins with a topic sentence. There are almost three paragraphs in the middle part where each of the paragraphs begins with a topic sentence. The topic sentence is substantiated by different examples, facts, and supporting details. Finally, a conclusion is drawn where the thesis statement is desired to be restated.
Proficiency Level: Intermediate to advance

Age Group: Young/adult

Teaching Hour: 90-100 minutes

Objectives: On completion of this lesson, students will be able to: 1 . share their personal experiences about essay writing, 2. define the components and forms of essay writing, 3. learn how to write thesis statement and some topic sentences, 4 . learn how to support the topic sentence with other supporting details, 4 . write conclusion for an essay and reflect on the entire essay, 5 . engage, discuss and complete an essay.

Resources: Handouts and worksheets

\section{Procedure}

1. Scene setting: (10 minutes)

Start by sharing that essay writing can have different forms. Share your own understanding and experience about essay writing (three paragraph and/or five paragraph essay). Then, distribute the worksheets and ask students to read the sample of a five paragraph essay (See appendix-1). After a while, ask students to read the information provided on the back of the page. Once the students complete their reading, ask some questions related to their understanding. Make sure students have been aware of essay writing and its various components. 


\section{Pre-writing activities: (15 Minutes)}

Divide the students in pairs and ask the pairs to discuss what an essay is and elicit their opinions. You can facilitate this by allowing them to use their cell phones or the internet. Each pair shares their understanding with the whole group. Ask them to share about their understanding and different components of essay writing. Once the pairs become ready accomplishing their prescribed task, hold a discussion on the various components and forms of essay writing (three/five paragraph). The class listento their understanding about essay writing. To summarise the activity and conclude this activity, deliver a short instruction about thesis statement, topic sentences, supporting details, and concluding part of the entire essay.

\section{Discussion}

We can make a specific discussion on the following types of questions:

i. What types of essay is this?

ii. What is the essay about?

iii. Which is the thesis statement in the paragraph? Is it appropriate and meaningful in the first paragraph?

iv. What is the topic sentence in each paragraph? Do you find sufficient supporting details for each topic sentence? Do they create a flow in writing?

v. What about the last paragraph? Does this sentence conclude the main idea of the topic?
3. While writing activities: Generating ideas (35 minutes)

Prepare your students to write on some topics, for example; The Turning Point of My Life, Role of Youth in National Development, Use of Mobile Phone in Classroom, etc.

i. Thesis statement: (10 Minutes)

Divide the whole class into different groups. Ask them to discuss the possible sentences for thesis statement. When they become ready with thesis statement, they present in the class and get feedback from teacher.

Thesis statement

A thesis statement is a complete sentence that contains one main idea. This main idea controls the content of the entire essay.

A thesis statement contains subpoints and helps a reader know how the essay will be organized.

A thesis statement gives direction to the paper and limits what you need to write about.

All paragraphs of the essay should explain, support, or argue with your thesis.

A strong thesis statement is usually one sentence and often placed in introductory part.

ii. Topic sentence: (10 Minutes)

When the thesis statements are created, divide the students in pair and offer them the abovementioned topics, one for each. Most of the essay topics take the form of a direct question to answer, a statement to discuss, or atask to carry out(Levin, 1997). 
Instruct them to work in pair to write a topic sentence for each title. As soon as they present their topic sentences in the class, ask other pairs to give feedback. You also provide some constructive feedback.

\section{Topic sentence}

- Topic sentence also called the controlling idea of the paragraph.

- Every topic sentence has a topic (what we talk about) and controlling idea (what we say on a topic).

- Include about main points to support your topic sentence within the paragraph.

- It is written in a single sentence.

- It is simply written at the beginning of the paragraph, but sometime it can be in the middle or at the end of the paragraph.

iii. Supporting details: (10 minutes)

Instruct your students to write supporting sentences for the topic sentence they have already produced. Let each pair present their supporting details in the whole class and have discussion over each presentation. And discuss how the topic sentence is substantiated or supported by other details.

\section{Supporting details:}

- Supporting details contain facts, statements, examples, which guide us to conceptualize the main idea that the thesis statement indicate.

- Supporting details clarify, illuminate, explain, describe, expand, and illustrate the mains points.

- Supporting details are asserted immediately after the topic sentences are written.

- They demands cohesion and coherence in our entire essay.

- They justify the thesis statement and maintain a flow in our entire essay.

\section{i. Concluding paragraph: (10} minutes)

You ask them to write a concluding paragraph for what they have written. Students are encouraged to write and ask them to present, and give feedback on them.

\section{Concluding paragraph:}

It is the last paragraph of the essay.

It summarizes the details.

It is not the place to insert new ideas; rather it gives you an opportunity to wrap up your essay coherently.

It can be summed up either with the use of a closing statement or restating the thesis statement or summarizing.

It has to remind the reader of the main points from each of the body paragraphs. 
Proof reading and Editing: After the student prepare their first draft; ask them to work in group or pair. Students work in groups or pairs to edit their first drafts. They look at spelling, punctuation, grammatical correctness, and appropriateness. Likewise, the teacher asks them to revise their paragraph writing in terms of appropriate topic sentence, its supporting ideas, and conclusion. The teacher instructs them very clearly about connectives, transition, cohesion and coherence. The students try to practise as per the instruction.

Feedback Session: In this session, the teacher asks student exchange their produced essay. The members in each pair will be exchanged and are asked work sincerely to provide feedback. All the participants offer feedback on essays. Finally, the teacher provides constructive feedback and they correct their errors accordingly.

\section{Further practices: (10 Minutes)}

The teacher offers students some topics for short essays such as;

- $\quad$ My culture; My pride

- National Heritage of Nepal

- $\quad$ English as a Medium of Instruction

- $\quad$ Computer Assisted Learning

- $\quad$ Cell-phone Free Classroom, etc.

\section{Reflection:}

In this step, students practise essay writing as a process not as a product. They reflect on the processes they went through to produce an essay. Teacher further summarize the processes of writing an essay.

\section{References:}

Gardner, P. S. (2005). New direction: reading, writing and critical thinking. New York: Cambridge University Press.

Levin, P. (1997). Writing good essays: Reading and writing for undergraduates. Mcgraw: Open University Press.

\section{Appendix 1}

When I was young, I always knew that I wanted to become a teacher someday. When I played, I would often gather my dolls together and pretended to teach them how to do math problems or how to read a book. As I grew older, my desire to become an ESL teacher became clearer as I did come volunteer teaching overseas and in the United States. As I look on my reasons for becoming a teacher, there are three reasons that stand out. There are - my love for the English language, my innate interest in how people learn, and my desire to help other people.

I was much anxious about my career. I practise hard since I was very weak in English. I wanted to watch English movies from my childhood. My schooling was also very comfortable in English. I became habituated learning and practicing in English. I read the novels, watched English videos and practise a lot. In doing so, I happened to fell in love with love of English language to strengthen my personal career.

Interestingly, I was really worried on how people learn language all over the world. I didn't give up in my learning rather I tried my best to be the best kind of person I could personally be. I had a passion and a determined aim to be an EFL teacher. I struggled a lot whilst learning English language but I didn't hesitate to practise. I often tried to listen to my innate heart not what other people say. 
I had experienced tension and troubles of learning English language. I had experienced the experiences of people's difficulty in obtaining the better proficiency in English language. I had a hope and a strong zeal to help others. I wanted to help other people learn better. I did always think the best ways for enhancing English for my personal as well as professional life. However, I believed that the rigorous practice make anyone successful in his/her life.

Finally, after several hardships and struggle, I happened to gain a better and greater personal enhancement in English language. I felt as if I have achieved the goal I had targeted due to my own inner interest and desire. I was determined in such a way that I would not just learn English language rather I would help other people as well to learn. Thus, my inner interest, hard work and my love towards English language, etc. were the reasons for me to be an English teacher.

[In the above example, the italicised sentence in the introduction is the thesis statement. The bolded sentences are topic sentences in each of the three paragraphs and the last sentence of the essay is restatement of the thesis statement. ]

\section{Contributor:}

Ganesh Kumar Bastola, an M. Phil graduate of Kathmandu University is a teacher, teacher educator, researcher and translation practitioner. His areas of interests are narrative inquiry, teacher's pedagogical capital, professional development and translation.

Email: ganeshkumar.gb@gmail.com 